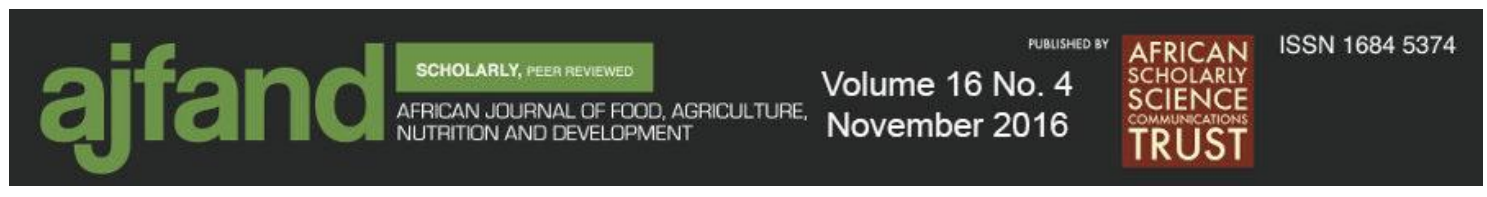

\title{
DOI: 10.18697/ajfand.76.15620
}

\section{WORLD PINEAPPLE PRODUCTION: AN OVERVIEW}

\section{Hossain $\mathrm{MF}^{1^{*}}$}

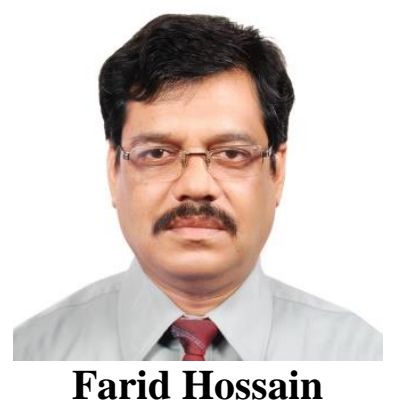

*Corresponding author email: faridhossain04@yahoo.com

${ }^{1}$ School of Agriculture and Rural Development, Bangladesh Open University, Gazipur1705, Bangladesh 


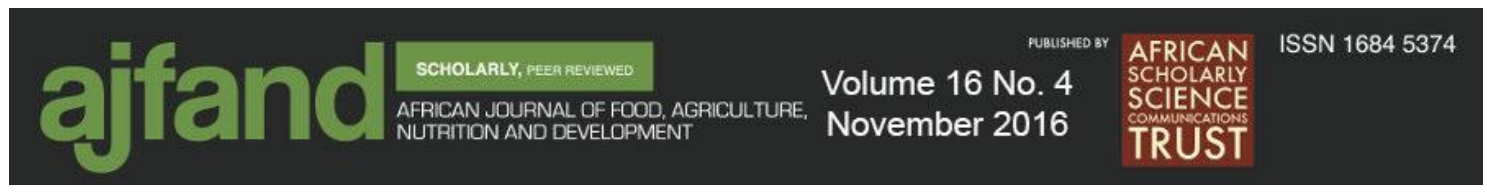

\begin{abstract}
This review paper discusses the origin, production, cultivation practices, storage, transportation and uses of pineapple. The economic importance of pineapple is easily justified by its unique characteristics as a fruit, which ensured its rapid diffusion and adoption, in the tropics and subtropics. Pineapple is a perennial monocotyledonous plant with a terminal multiple fruit. This perishable fruit is usually stored only for 4-5 days after harvesting in normal conditions. Generally, ripened pineapple fruit is consumed fresh or as pineapple juice. Thailand, Philippines, Mexico, Costa Rica, Chile, Brazil, China, Indonesia, Hawaii, India, Bangladesh, Nigeria, Kenya, Democratic Republic of Congo, Ivory Coast, Guinea, Dominican Republic and South Africa are the leading pineapple producing countries. Among the countries Philippines, Thailand, Costa Rica, Indonesia, Chile, Ivory Coast and South Africa are the major exporters of pineapple in the world market. Quality of pineapple varies due to cultivation technique, growing environment and variety. Good quality pineapple grows well in acidic loams, sandy loams and clay loams soils under warm and humid climate with sunny days and cool nights. Pineapples need a neutral to mildly acidic soil ranging $\mathrm{pH}$ from 4.5 to 6.5 . Pineapple reproduction is through vegetative propagation using suckers and crowns. Fertilizer requirement increases sharply after planting and peak at two to four months before floral initiation. Earthing up operation gives better anchorage to the plants. Mulch promotes rooting by concentrating moisture, increasing soil temperature in the root zone and controlling weeds. Irregular flowering behavior of pineapples also affects its commercial yield adversely. A variety of chemicals are available to achieve uniformity and control flowering. Storage and transportation facilities are the important factors for local and international marketing. Harvested fruits are packed in the crates and transported in refrigerated containers for quality assurance. The prospect of pineapple is bright due to increasing trend of total consumption and export potential.
\end{abstract}

Key words: Pineapple, Origin, Distribution, Climate, Propagation, Intercultural operations, Post-harvest operations, Uses 


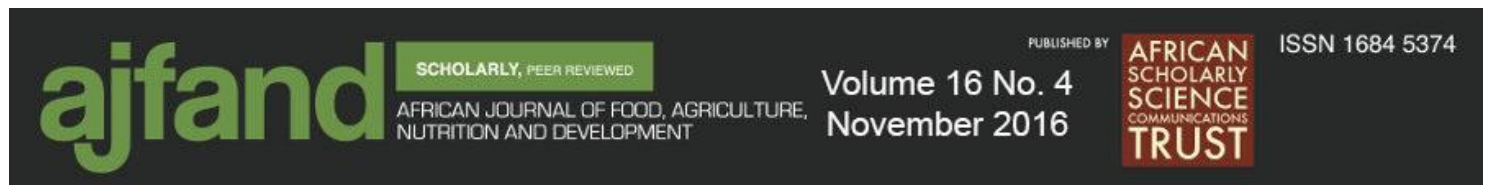

\section{INTRODUCTION}

Pineapple [Ananas comosus (L.) Merr.] is a tropical fruit with exceptional juiciness, vibrant tropical flavor and immense health benefits. Mature fruit contains sugar, a protein digesting enzyme bromelin, citric acid, malic acid, vitamin A and B [1]. It can be used as supplementary nutritional fruit for good health with an excellent source of vitamins and minerals and contains considerable calcium, potassium, fiber, and vitamin $\mathrm{C}$. Pineapple is the third most important tropical fruit in the world after banana and citrus $[2,3]$. The five leading pineapple producing countries are Costa Rica, Brazil, Philippines, Thailand and Indonesia [4]. These countries produce the fruit primarily for fresh fruit markets and the processing industry. It can increase national income through the expansion of local industries and higher incomes for farmers involved in its production. This fruit is much liked and popular all over the world. Pineapples may be cultivated from a crown cutting of the fruit, possibly flowering in 20-24 months and fruiting in the following six months.

Pineapples are consumed or served fresh, cooked, juiced and can be preserved. The fruit is eaten fresh where available and in canned form worldwide. This fruit is highly perishable and seasonal. Therefore, the main objective of this paper is to review the global production technologies, uses and potential opportunities of pineapple in the world market.

\section{ORIGIN, DISTRIBUTION AND PRODUCTION}

The origin of pineapple has been traced to Brazil and Paraguay in the Amazon basin where the fruit was first domesticated [5]. Worldwide production started by $15^{\text {th }}$ century. Pineapple was distributed in Europe and the tropical regions of the world. The most spread variety is Smooth Cayenne (Cayena lisa), which was first introduced in Europe from French Guyana [6]. Pineapple production is concentrated in the tropical regions of the world. It is grown in over 82 countries with over 2.1 million acres under the fruit [7]. The smooth Cayenne cultivar is extensively cultivated in many tropical countries like Hawaii, Philippines, Australia, South Africa, Puerto Rico, Kenya, Mexico, Cuba and Formosa [8]. Nigeria is ranked 7th on the list for world pineapple production as well as the leading producer in Africa [9]. It was until late $19^{\text {th }}$ century when canned pineapple was produced commercially in Hawaii. Other important producers include India, Nigeria, Kenya, Indonesia, México and Costa Rica and these countries provide most of the remaining fruit available (50\%) [6]. There exists several hundred varieties, but the most widely grown are Smooth Cayenne, Queen and in the past decade introduced variety called MD2 which commands $80 \%$ of the global trade in pineapples [7]. Pineapple production in 2011 constituted more than 19 million metric tons (MT). Thailand is the largest producer of pineapple, accounting for $13 \%$ of global output, followed by Brazil and Costa Rica [10]. World pineapple production was 23.33 million metric tons in 2012 and showed gradually increasing trends from 2002 to 2012. The world pineapple market has been expanding rapidly for the last twenty years [11]. 

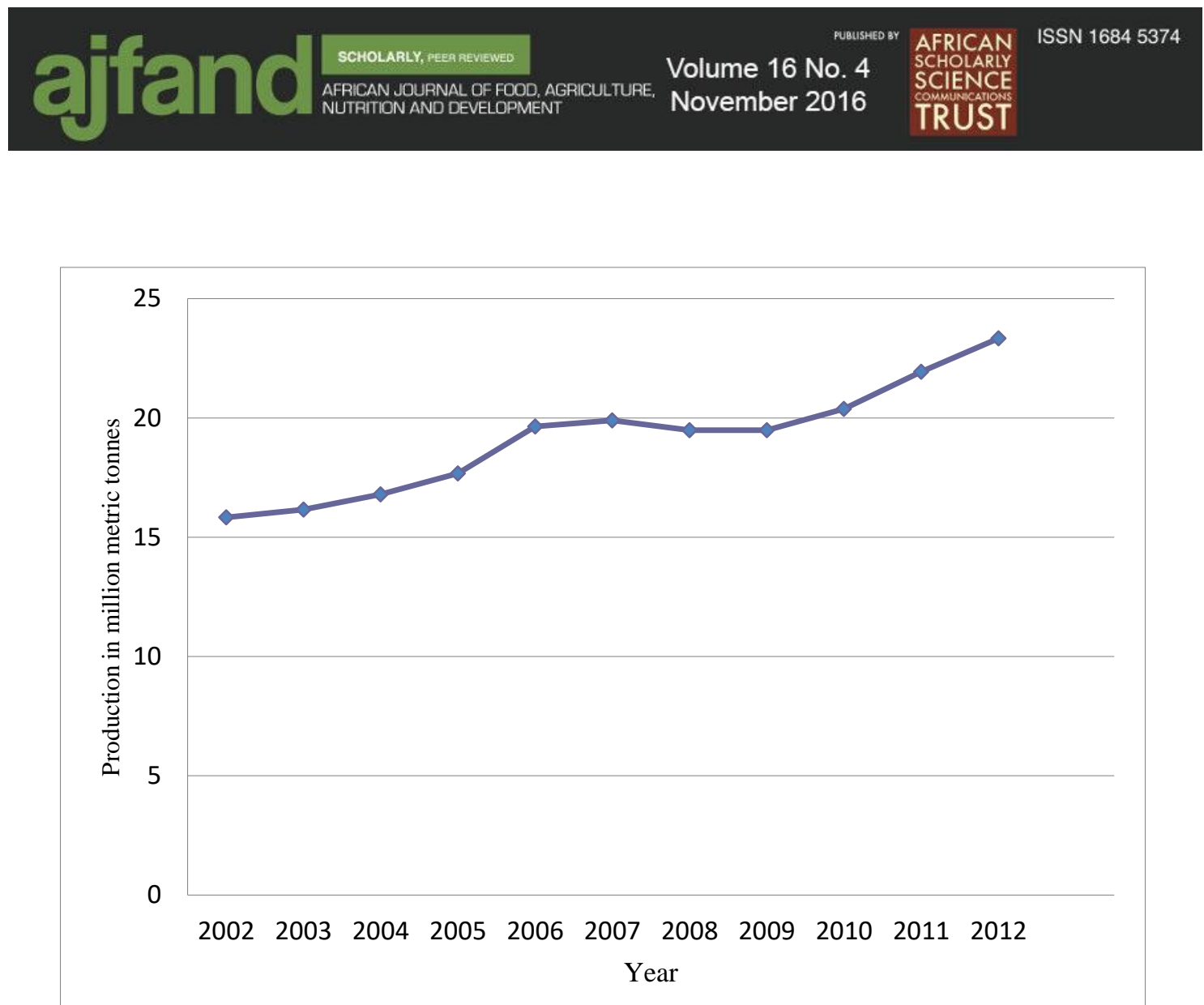

Figure 1: Pineapple production in the world (2002-2012) [11]

Twelve countries absorb $90 \%$ of the world demand of fresh pineapple. The US leads the demand, while France, Japan, Belgium, Italy, Germany, Canada, Spain, England, Korea, Netherlands and Singapore share the rest of the supply [12]. Nigeria, Kenya, Democratic Republic of Congo, Ivory Coast, Guinea and South Africa are the major pineapple producing countries in Africa [11]. Pineapple production is very significant to the economy of Kenya in terms of creating employment and foreign exchange. Expansion of pineapple production system will therefore lead to more benefits to the economy of Kenya. In Kenya pineapple is predominantly grown by large scale producers. Large-scale production is concentrated in Central Kenya, while the small scale production is concentrated at the Coast, Central and Western Regions of the country. Large-scale pineapple production in Kenya is dominated by three farms; Delmonte $(\mathrm{K})$ Limited based in Thika, Kakuzi limited based in Murang'a and Ndemo farm based in Kilgoris. Kakuzi has a total of 100 ha under pineapple while Delmonte has 18,000 ha and Ndemo farm has 200 ha under pineapple production. These large-scale producers contribute close to $90 \%$ of all pineapples grown in Kenya. Medium scale and small-scale producers account for about $10 \%$ of the total pineapple production. Most of the land utilized for pineapple production by Delmonte and Kakuzi is under long-term lease from the Government [7]. The most planted variety is smooth cayenne accounting for $80 \%$ of the total pineapple produced, though currently there are efforts to move to MD2 variety due to its superior nutrition qualities [13]. 


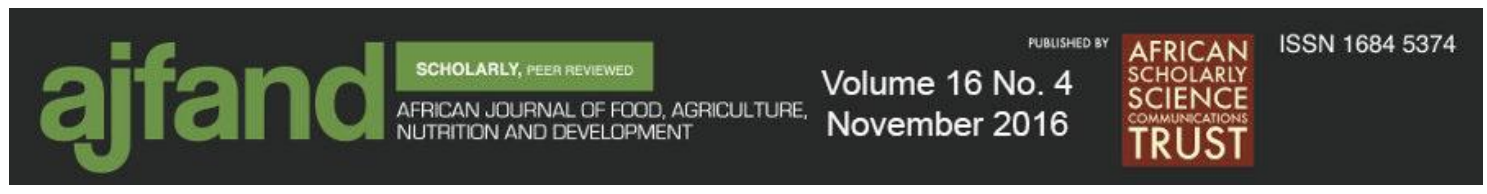

\section{CLIMATIC REQUIREMENTS}

Pineapple grows in warm and humid climate. The pineapples are commercially grown over a wide range of latitudes from $30^{\circ} \mathrm{N}$ in the northern hemisphere to $33^{\circ} 58^{\prime} \mathrm{S}$ in the Southern hemisphere [14]. Pineapple grows well in tropical and subtropical climate ranging from mild coastal climate up to an altitude of about 1000 meters provided the area is free from frost [15]. When pineapple is grown at altitudes greater than $1000 \mathrm{~m}$ smaller fruits with elevated tartness are produced and the pulp is less attractive in color and flavor [16]. The optimal growth temperature lies between 20 to $30^{\circ} \mathrm{C}$ and more specifically at $23-24^{\circ} \mathrm{C}[17,18]$. When ambient temperature drops between 10 to $16^{\circ} \mathrm{C}$, fruit growth is constrained. Plants may stand sub-freezing temperatures for very short periods. Conversely, with exposure to temperatures well over $30^{\circ} \mathrm{C}$ heat damage may occur due to increased respiration rate and metabolism and impaired nutrient absorption [19]. During periods of intense sunlight and high temperature above about $35^{\circ} \mathrm{C}$, the fruit is susceptible to sunburn damage [20]. Good fruit quality is attributed to growing sites having a combination of relatively cool night temperatures, sunny days and day temperatures ranging from 21 to $29.5^{\circ} \mathrm{C}$ obut not exceeding $32^{\circ} \mathrm{C}$ [21]. It can be grown in areas that have a relatively high atmospheric humidity and an average rainfall of 760-1,000 $\mathrm{mm}$ [22]. The damage caused by sunburn in pineapple production areas in the world where this fruit is harvested can be very important in periods when solar radiation is high. Percentages of reject fruit because of this damage can be over $40 \%$ in some months of the year if preventative actions are not taken [23]. Severe cold reduces the sweetness of fruits. Strong sunshine causes sun burning on fruits. Hence partial shade is desirable in areas receiving high intensity of sunlight. It requires well distributed annual rainfall [24].

\section{EDAPHIC REQUIREMENTS}

The best soils for pineapple production are well drained non-compacted loams, sandy loams and clay loams with no heavy clay or rock within one meter of the surface. A soil $\mathrm{pH}$ in the range of 4.5-5.6 is optimal for pineapple production. Slopes between 2-6\% are best for pineapple growing. Below this range, it may be hard to achieve adequate drainage [19]. Acidic soil rich in organic matter and potassium is desirable to pineapple cultivation [20]. The flavor and quality of fruit grown on light soils is considered to be superior. The plant is particularly sensitive to waterlogged soil conditions [21]. On the hills it can be grown successfully provided the soil depth is at least 45 to $60 \mathrm{~cm} \mathrm{[22].}$

\section{MORPHOLOGY}

Pineapple is a herbaceous plant. The main morphological structures of the plant are stem, leaves, peduncle, crown, shoots and the adventitious roots [25]. The peduncle and inflorescence develop from the apical meristem [26]. The root system is primarily adventitious, typical of monocots, and may spread up to $1-2 \mathrm{~m}$ laterally and $0.85 \mathrm{~m}$ in depth under optimal conditions [27]. Root growth commences soon after planting and continues up until around flowering. Root growth slows but continues throughout winter 


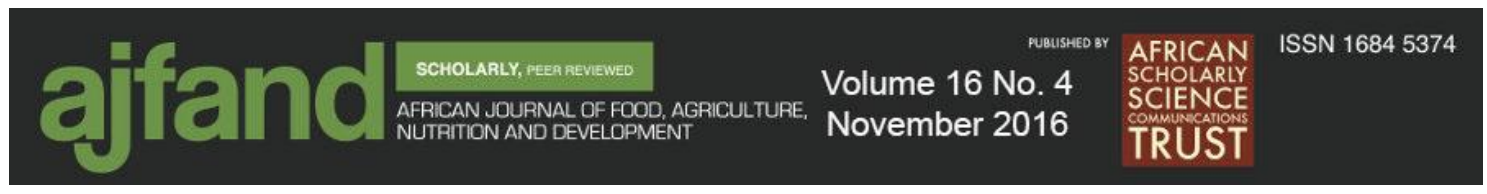

depending on temperatures and soil moisture [28]. A pineapple plant has many leaves (68-82) arranged in the form of a dense compact rosette. The older leaves are located at the base of the plant and the younger ones in the center. Flowers contain both the male and female reproductive organs [27]. The flower petals are white at their base; to violetblue at their tip and are tongue-shaped. Each flower is surrounded by a thick bract, which is covered by trichomes and pointed at its tip. The sepals are more or less triangular in shape and are comparable to the bracts in color and texture. The flowers are arranged in a narrow compact tubular manner that only insects or specialized birds can access [29]. The fruit usually contains a tuft of small leaves at the top known as the crown that may be used for vegetative propagation [28].

\section{CULTIVATION TECHNOLOGY}

\section{Propagation}

Pineapple is propagated asexually from various plant parts. The parts are crowns, slips and suckers. Crowns and slips are most common. Tissue culture is used for rapid increase of strain selections [15].

Crowns: Crowns are currently the preferred planting materials which are cut from the fruit at harvest. The wound is allowed to dry (cure) and the crowns are dipped in fungicide and planted soon after harvest. Crowns grow more slowly and are less drought resistant than slips but may have the potential to develop better root systems. Crowns should be graded by weight to minimize variability in the field [15].

Slip: Slip is a rudimentary fruit with an exaggerated crown. Slips develop from buds in the axils of leaves borne on the peduncle (fruit stalk). Slips become visible on the peduncle when the fruit is about half developed. Slips are broken from the peduncle, then cured or dipped in fungicide. Slips may be stored in a dry place for up to one year, but they should be planted within one month of harvest for best results [15].

Suckers: Suckers develop from axillary buds on the stem. Growth usually begins at floral differentiation. After fruit harvest, suckers are cut from the stem with a knife. Desuckering should be done immediately after harvest leaving only one sucker on the mother plant. Slips should also be removed. It is advisable to renew the plantation every 5-6 years [22].

Seeds: Commercial propagation of pineapple is not through seeds but by vegetative propagation [30]. Seeds are desired only in breeding programs and are usually the result of hand pollination [31]. Seed is viable short time. Longevity of hybrid seeds has been estimated to be less than six months in storage in Cote d'Ivoire [32]. In addition, there does not appear to be any seed dormancy in pineapple seeds [33].

\section{Fertilization}

Pineapple has high requirements for nitrogen $(\mathrm{N})$, potassium $(\mathrm{K})$, and iron $(\mathrm{Fe})$, while relatively low requirements for phosphorus $(\mathrm{P})$ and calcium $(\mathrm{Ca})$. Potassium is usually applied to the soil before planting and later as side dressing. Other nutrients sometimes including $\mathrm{K}$ are applied as foliar sprays or through the drip irrigation system, or by both 
methods, during the growth cycle. Phosphorous and Ca are usually banded in the plant line during bed preparation. Less fertilizer is required during the first five months after planting but requirements increase sharply afterward and peak at two to four months before floral initiation [20].

\section{Earthing up}

Earthing up is a very important operation in pineapple cultivation and involves pushing soil to the base of the plant from the periphery or into the trench from the ridge, where trench planting is common. Due to its shallow root system and weak stem pineapple plants are prone to lodging [34]. Earthing up gives better anchorage to the plants and should be done after each application of fertilizers and also after weeding, hoeing and harvesting of crops. This becomes more important in ratoon crops [22].

\section{Irrigation}

In general, pineapple requires a minimum monthly rainfall total of $50-100 \mathrm{~mm}$. If the annual rainfall is less than $500 \mathrm{~mm}$, irrigation is essential [35]. Pineapple plants are drought tolerant, therefore, the schedule for irrigation at the time of planting and thereafter should be intermittent. The growth of pineapple plant is retarded due to seasonal drought and water shortage. Available water for irrigation is recommended in drier areas and is useful in planting, and at 8-12 weeks before harvesting. Pineapples are sensitive to saline water [19].

\section{Mulching}

Mulching is an important practice in pineapple production. Film mulching can modify the microclimate, reduce water evaporation from soil and maintain the soil humidity [26]. It can also efficiently inhibit the growth of weeds, promote the plants growth and increase the yield and quality of crops [34]. Film mulching could also increase some physiological properties, such as contents of chlorophyll, soluble sugar, and protein of pineapple leaves and roots [36].

\section{Induction of Flowering}

Irregular flowering behavior of pineapples affects its commercial yield. The effectiveness of flower induction mainly depends on the type of flower induction agent, the mode of application, plant genotype and environmental conditions that is temperature, humidity, wind, rainfall [3]. Pineapple flowering is uneven and it is highly desirable to attain uniform maturity and to control the time of harvest in order to avoid overproduction during peak periods. Several chemicals are available and can be used to achieve uniformity and control over flowering. Synchronization of flowering is an essential component of pineapple (Ananas comosus var. comosus) cultivation, especially for those cultivars intended for fresh consumption [37]. It is important to apply the correct flowering induction agent at the right time [38]. A suitable ethylene concentration used for commercial flowering induction is $2.272 \mathrm{~kg} \mathrm{ha}^{-1}$ ethylene gas sprayed with $7000 \mathrm{~L}$ $\mathrm{ha}^{-1}$ water [37].

\section{Maturation, ripening and harvesting}

Pineapple plants that are vegetative propagated will bear fruit in 15-22 months [31]. More than three months are necessary from flowering to fruit maturity in pineapple [30]. Fruits 


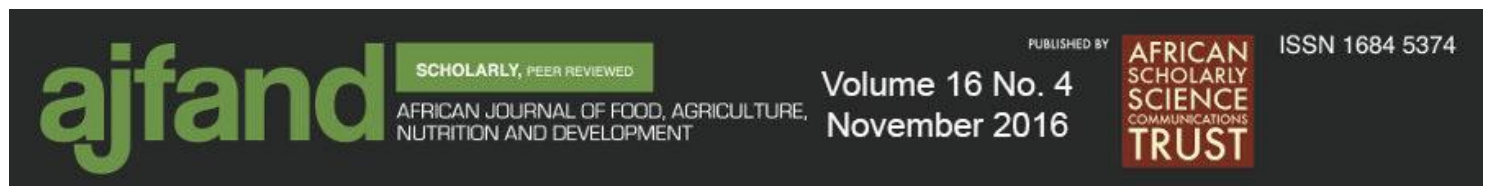

for canning are acceptable at a more advanced stage. Over-ripe fruits are highly perishable. Therefore, for optimum fruit sweetness, pineapple fruit should be harvested when $1 / 3$ to $2 / 3$ or more of the peel color has turned from green to yellow. Harvesting of fruits can be manual or semi-mechanized [30].

\section{Post-harvest operations}

Grading: After pre-grading, washing, waxing, and fungicide treatment, the pineapples are left to dry and then are graded for packing. Graders remove any fruit that shows signs of fresh mechanical damage or any of the conditions that qualify the fruit for rejection in the pre-grading stage. Remaining pineapples are classified for packing based on size, stage of ripeness, and, where applicable, shape. Fruits of different shapes may not be mixed in the same carton [6].

Pre-cooling: The fruit is gradually pre-cooled before packing. This allows the fruit to cool down over a 12-hour period from the ambient temperature at delivery time [6].

Packing: All cartons of fruit are checked by quality control personnel before the carton is sealed and placed in a cooler until shipment time. The cartons of fruit are stacked on pallets and these pallets are placed in a shipping cooler, where temperature is maintained between $8-10{ }^{\circ} \mathrm{C}[6]$. Where sea-shipment is to be used, the fruit should be harvested on the day prior to shipment.

\section{STORAGE AND TRANSPORTATION}

Storage: Green fruit should be stored at a temperature of $10^{\circ} \mathrm{C}$ and a relative humidity of $85-95 \%$. Under these conditions, the fruit should have a storage life of two to three weeks. This will be dependent on the sugar content and the agronomic conditions during production, in addition to the handling and storage procedures [6]. Sensitivity to chilling injury is, however, related to the level of ripeness of the fruit. Storage of green fruit below $8^{\circ} \mathrm{C}$ will result in chilling injury symptoms such as incomplete color development, wilting and darkening of the flesh, crown and peel [39]. After harvesting, clean the fruits and cut the stalks to $2 \mathrm{~cm}$. Sort out the fruits to make sure that only half-ripe or greenripe fruits, which are free from damage and pest and disease, are presented for sale.

\section{Storage methods:}

1. Normal temperature storage: Pineapple stored by normal temperature, storage period generally short, the fresh quality assurance is within 7 10 days. The store should be with fresh air, intact doors and windows, and the exhaust fan shall be equipped for to ventilation [40].

2. Basket storage method: The pineapple harvested properly should be cooled keeping in a pre-cooled place/shelter and then only the fresh pineapple should be packed in a basket after treating with preservative keeping all the damaged pineapple aside. The storage temperature should be controlled within $7-10^{\circ} \mathrm{C}$ and relative humidity should be $85-90 \%$. During the storage period it should ventilate 


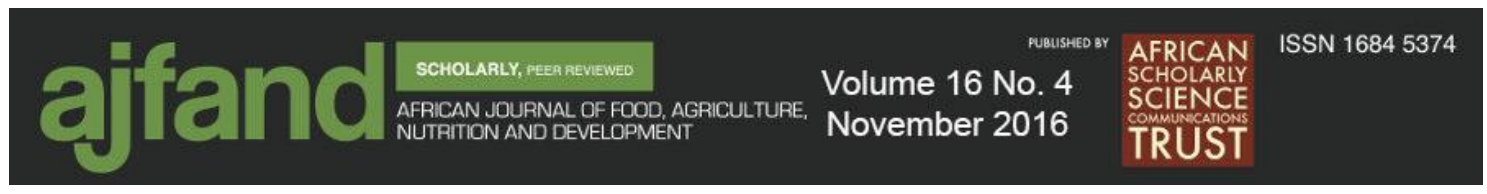

by keeping air flow and check to remove the damaged fruit regularly. The pineapple can be stored for more than 20 days by using this method [40].

3. Plastic bag storage method: The pineapple should be dipped in a solution of 500 ppm naphthylacetic acid and then dried by air flow or keeping it in air. Then the treated pineapple should be inserted into a plastic bag which is padded with rough straw paper to absorb the moisture and to avoid any damage. Then the open end of the bag should tie up and store it in a cool place keeping the temperature within $7-10^{\circ} \mathrm{C}$. The fruit can be stored well for more than one month without any damage and keeping the quality remains good [40].

Transportation: Transport of pineapples for export should be done in refrigerated trucks or containers. Product stacking will depend on the type and size of container and must be carefully planned to minimize physical damage [6]. Fruits with crown can be kept without damage for 10-15 days after harvesting. When fruits are transported for long distances or for a period of several days, refrigerated transport is required to slow down the ripening process. Pineapples can be stored well for a period of 20 days when refrigerated at $10-13{ }^{\circ} \mathrm{C}$. The best storage is at $7.2^{0} \mathrm{C}$ and 80 or $90 \%$ relative humidity [41].

\section{USES OF PINEAPPLE}

Food: The pineapple fruits are normally eaten fresh or as fresh pineapple juice. Pineapple ripened in plants is best eaten fresh and it is only necessary to remove the crown, rind, eyes and core. In the Philippines, the fermented pulp is made into a popular sweetmeat called nata de pina. In Africa, young, tender shoots are eaten in salads. The terminal bud or "cabbage" and the inflorescences are eaten raw or cooked. Young shoots, called "hijos de pina" are sold in vegetable markets in Guatemala [32]. Pineapple fruits exhibit high moisture, high sugars, vitamin $\mathrm{C}$ and low crude fiber. The pineapple waste contains non reducing sugars and carbohydrates and protein which are used as a nutrient medium for growth of microbes and fermentation using yeast to produce ethanol and single cell protein [2].

Medicine: In addition to its nourishing uses, pineapple has long served medical purposes in folk medicine. It is used to arouse appetite, is effective as a diuretic, contraceptive and in the expulsion of intestinal worms. It has been used to prevent ulcers, enhance fat excretion, among many other uses. Pineapple is the source of the proteolytic enzyme bromelain which is used in commercial meat tenderizers and which constitutes practice as a soft tissue anti-inflammatory and for topical debridement [42].

Fiber: Pineapple leaves yield a strong, white, silky fiber and certain cultivars are grown especially for fiber production and their young fruits are removed to give the plant maximum vitality. The 'Perolera' is an ideal cultivar for fiber extraction because its leaves are long, wide and rigid. The retted material is washed clean, dried in the sun and combed [3]. From long years ago in Malacca and Borneo the "Perolera" is used to make thread. In India the thread is prized by shoemakers and it was formerly used in the Celebes. In West Africa the pineapple fiber has been used to string jewels and also to weave the caps 
of the tribal chiefs. People of Kwangtung province and the Hainan Island of use the pineapple fiber to weave coarse textiles which looks like grass cloth. In Guam, people use this fiber to wrap or sew cigars and hand twists the fiber into casting net. In Panay, an Island of Philippines, and in Taiwan 'Pina' cloth is highly valued. In Taiwan pineapple fiber also used to weave coarse cloth for farmer's underwear [32].

Uses of pineapple wastes: Pineapple peel solid waste can be generated successfully to be a methane gas of an attractive concentration of $48 \%$ at 20 days by using the indigenous microorganism. The biodegradation of pineapple peel solid waste to methane gas expressed the potential for waste treatment through anaerobic digestion. Biogas production from industrial waste of pineapple was not only performed the solutions for alternative green energy, but also play an important role to keep pollution free environment [43].

Feed for animal: The outer peel or skin and core from the pineapple canning industries, called bran, and the leaves are being utilized as feed for ruminants. Cattle preferred fermented pineapple waste with higher acidity to fresh waste and pineapple waste from the field or from the cannery are being used as dairy feed. Dried and ensiled pineapple waste can be used as supplemental roughage and could replace $50 \%$ roughage in the total mixed ration for dairy cattle [44].

\section{CONCLUSION}

This review aimed at providing in-depth information about the pineapple in different aspects. It is a highly nutritious fruit, has numerous health benefits and provides economic potential for farmers, entrepreneurs and consumers. Quality of pineapple varied due to growing environment, cultivation technique, harvesting time, storage and transportation facilities. The prospect of pineapple farming is bright in the growing countries due to increasing consumption and export potentiality in the world markets. To facilitate the distribution of the highly perishable fruit authorities should establish modern storage and transport facilities wherever necessary. Extensive research should also be undertaken to develop new technologies for increasing the yield and maintain quality of pineapple from production to marketing stage. For good economic returns from pineapple, growers should pay due attention for considering all recommended practices based on locality. The availability and accessibility of food can be increased through improved production technology, distribution and preservation systems. 


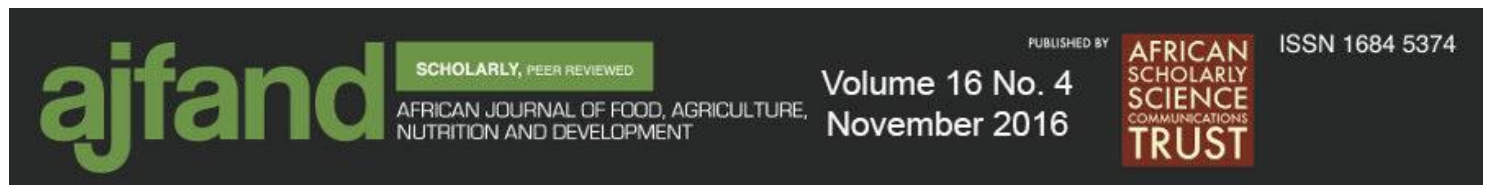

\section{REFERENCES}

1 Joy PP Benefits and uses of pineapple. Pineapple Research Station, Kerala Agricultural University, Vazhakulam-686 670, Muvattupuzha, Ernakulam District, Kerala, India. 2010.

http://www.kau.edu/prsvkm/Html/BenefitsofPA.htm Accessed on 21 December 2014.

$2 \quad$ Hemalatha R and S Anbuselvi Physicochemical constituents of pineapple pulp and waste. J. Chem. Pharmaceutical Res. 2013; 5(2):240-242.

3 Rohrbach KG, Leal F and GCD 'Eeckenbrugge History, Distribution and World Production. In: Bartholomew DP, Paul RE and KG Rohrbach (Eds). The pineapple: Botany, Production and Uses, University of Hawaii Manoa Honolulu, USA.CABI Publishing, CAB International. 2003.

http://s3.amazonaws.com/zanran_storage/bookshop.cabi.org/ContentPages/2453 745808.pdf Accessed on 1 November 2014.

4 Food and Agriculture Organization of the United Nations Statistics Division (FAO STAT) 2013.

http://faostat3.fao.org/browse/rankings/countries_by_commodity/E Accessed on 15 July, 2014.

5 Collins JL History, taxonomy and culture of the pineapple. Economic Botany, 1949; 3(4): 335.

6 Medina JDLC and HS García PINEAPPLE: Postharvest Operations. Food and Agriculture Organization of United Nations, 2005.

http://www.fao.org/fileadmin/user_upload/inpho/docs/Post_Harvest_Compendi um_-_Pineapple.pdf (Accessed on 3 July, 2014).

$7 \quad$ Ndungu SA report on conventional pineapple production in Kenya. Swedish Society for Nature Conservation (SSNC), Sweden, 2014. http://www.naturskyddsforeningen.se/sites/default/files/conventional_pineaple_ production_kenya.pdf (Accessed on 25 December, 2014).

8 Azevedo PVD, Souza CBD, Silva BBD and VPRD Silva Water requirements of pineapple crop grown in a tropical environment, Brazil. AgrWater Manage. 2007;88: 201-208.

9 Food and Agriculture Organization Corporate Statistical Database (FAOSTAT) $2011 \mathrm{http}: / / \mathrm{www}$. fao.org/ August 30, 2013).

10 Baruwa OI Profitability and constraints of pineapple production in Osun State, Nigeria. Journal of Horticultural Research.2013; 21(2):59-64. 


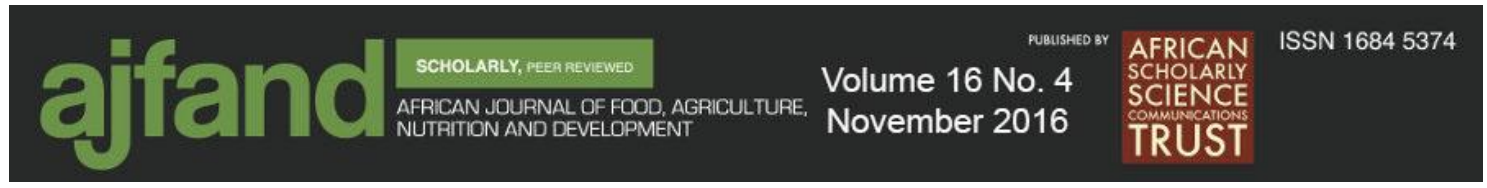

11 The United Nations Conference on Trade and Development (UNCTAD) Pineapple. http://www.unctad.info/en/Infocomm/AACPProducts/COMMODITY-PROFILE---Pineapple/ Accessed on 25 December 2014).

12 Ministry of Agriculture and Fisheries, Jamaica Pining for the flavor. RDA Newsletter, 31 July, 2010; 1.6.

http://www.moa.gov.jm/MarketWise/marketwise_pineapple.pdf. Accessed on 10 December 2014.

13 Koech W, Gicuru KI and LK Kibet Evaluating Technical Efficiency of Smallscale Pineapple (Ananascomosus) Production in Bureti District, Kenya Research Journal of Social Sciences, 2013;5(6): 192-196.

14 Malezieux E, Cote F and DP Bartholomew Crop environment, Plant growth and Physiology. In: in Bartholomew DP, Paull RE and Rohrbach KG (Eds) The Pineapple-Botany, Production and Uses, Wallingford, CABI, 2003; 69108.

15 Sing VB Fruits of NE Region: Package of Practice for Pineapple http://megapib.nic.in/pppineapple.htm. Accessed 9 December 2014.

16 Purseglove JW Tropical crops: Monocotyledons, Vol.1, John Wiley \& Sons. New York.1968; 334.

17 Neild RE and $\mathbf{F}$ Boshell An agro-climatic procedure and survey of the pineapple production potential of Colombia. Agric. Met.1976; 17: 81-92.

18 Py C, Lacoeuilhe JJ and C Teisson The pineapple, cultivation and uses. Paris: G.P. Maisonneuve\& Larose. 1987: 568.

19 Bartolomew DP and SB Kadzimann Ecophysiology of tropical crops. In: P.T. Alvin and T.T. Kozlowski (Eds). New York. Academic Press. 1987; 502.

20 Pineapple-Land requirements for growing pineapple. Department of Agriculture and Fisheries. Queensland Government. https://www.daff.qld.gov.au/plants/fruit-and-vegetables/fruit-andnuts/pineapples/land- requirements-pineapple. Accessed on 31 October, 2014.

21 Pineapples-Cultural practices Information system of tropical crops in Hawaii Department of Tropical Plant \& Soil Sciences University of Hawaii at Manoa. http://www.ctahr.hawaii.edu/fb/pineappl/pineappl.htm Accessed on 8 November 2014.

22 Pineapple-Soil and Climate http://nhb.gov.in/fruits/pineapple/pin012.pdf. Accessed on 12 December 2014. 


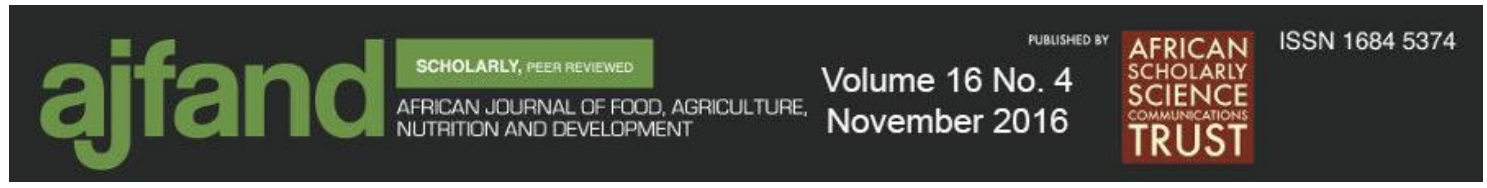

23 Gonzalez AC and FR Espinoza Pineapple news, Saran Shade Cloth to Prevent Sunburn in Pineapple Fruit. Newsletter of the Pineapple Working Group, International Society for Horticultural Science June, 2008; Issue no.15: 21-23.

24 Growing Pineapples Tropical Permaculture http://www.tropicalpermaculture.com/growing-pineapples.html Accessed on 29 December 2014.

25 Zhang J, Ren XL, Luo SF, Hai JB and ZK Jia Influences of different covering materials mulching on soil moisture and corn yield. Transactions of the CSAE, 2010; 26(6):14-19.

26 D'Eeckenbrugge GC and F Leal Morphology, Anatomy and Taxonomy. In: Bartholomew, DP, Paull, RE and Rohrbach, KG (Eds). The Pineapple: Botany, Production and Uses. CABI Publishing, Oxon, UK. 2003:13-32.

27 Bartholomew DP, Paull RE and KG Rohrbach The pineapple: botany, production and uses. Bartholomew, D.P., Paull, R.E., Rohrbach, K.G. (Eeds). CABI Publishing, Wallingford, UK.2003; 1-301.

28 Pineapple best practice manual, Chapter-01: The pineapple, Version 1, 31 August 2009

https://www.daf.qld.gov.au/_data/assets/pdf_file/0007/66247/Ch1-ThePineapple.pdf. Accessed on 15 July, 2014.

29 Coppensd'Eeckenbrugge $\mathbf{G}$ and $\mathbf{F}$ Leal Fruits from America: An ethno Botanical inventory,

2001.http://www.ciat.cgiar.org/ipgri/fruits_from_americas/frutales/Ficha\%20An anas\%20comosus.htm;http://www.ciat.cgiar.org/ipgri/fruits_from_americas/frut ales/more\%20about\%20pineapple.htm. Accessed on 12 August, 2014.

30 The Biology \& Ecology of Pineapple in Australia. April 2003. http://www.ogtr.gov.au/internet/ogtr/publishing.nsf/content/pineapple3/\$FILE/pineapple.pdf. Accessed on 6 December 2014.

31 Kerns KR, Collins JL and H Kim Developmental studies of the pineapple Ananascomosus (L.) Merr. The New Phytologist, 1936; 35:305-317.

32 Morton J Fruits of warm climates. Creative Resource Systems, Inc. NC.1987:1828.

33 Loison-Cabot $\mathbf{C}$ and JJ Lacoeuilhe A genetic hybridization programme for improving pineapple quality. Acta Horticulturae, 1990; 275:395-400.

34 Joy PP Production technology for Vazhakulam Pineapple (Mauritius) http://www.kau.edu/prsvkm/Html/ProdnTechVkmPA.htm. Accessed on 9 July 2014. 


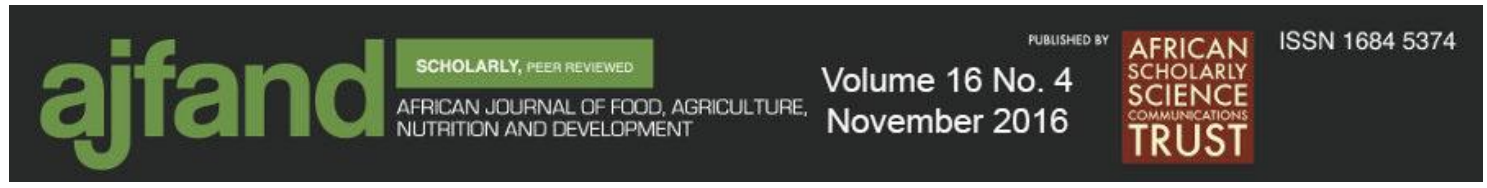

35 Carr MKV The water relations and irrigation requirements of pineapple (Ananascomosusvar. comosus): A Review. Expl Agric. Cambridge University Press, 2012; 1-14.

36 Liu C H, Liu Y, Yi G J, Zhong Y and BJiang Effects of plastic film mulching on several physiological indexes of pineapple plants. Chinese J. Trop. Crops, 2008; 29(5):546-550.

37 Hepton A Cultural system. In: Bartholomew DP, Paull R, and Rohrbach KG (eds) The pineapple: Botany, Production and Uses. CABI Publishing, Wallingford, UK, 2003; 109-142.

38 Min XJ and DP Bartholomew Effect of plant growth regulators on ethylene production, 1-aminocyclopropane-1-carboxylic acid oxidase activity, and initiation of inflorescence development of pineapple. J. Plant Growth Regul. 1996; 15 (3):121-128.

39 Pineapple production practices. National Agricultural Research Institute. Mon Repos, East Coast Demerara, 1999.

http://businessafrica.net/africabiz/pineapple_booklet.pdf. Accessed 13 April, 2014.

40 http://www.xd1-mcp.com/en/index.php?c=article\&id=404 Accessed on 8 July, 2014.

41 Pineapple http://nhb.gov.in/report_files/pineapple/PINEAPPLE.htm Accessed on 12 December 2014.

42 Omojasola P, Folakemi, Jilani, Omowumi Priscilla and SA Ibiyemi Cellulase Production by some Fungi Cultured on Pineapple Waste.Nature and Science, 2008;6(2):64-79

43 Chulalaksananukul S, Sinbuathong N and W Chulalaksananukul Bioconversion of Pineapple Solid Waste under Anaerobic Condition through Biogas Production. KKU Res. J. 2012; 17(5):734-742.

$44 \quad$ Hossain M and RH Bepary Post-Harvest Handling of Pineapples: A Key Role to Minimize the Post-Harvest Loss. International Journal of Recent Scientific Research, 2015; 6(9):6069-6075. 